\title{
COMPARISON OF CONTENT AND LANGUAGE INTEGRATED LEARNING IN THE PRIMARY LEVEL IN SPAIN AND SLOVAKIA
}

\author{
Barbora Pavelová \\ University of Prešov, Slovakia
}

\begin{abstract}
As many authors agree, positive associations of Content Language Academic Learning have attracted numerous researchers, administrators, teacher educators and teachers, particularly those in the field of English as a foreign language. One of the main goals of the presented article is to offer a comparative analysis of CLIL approach at primary level in Spain and in Slovakia. The need for elaborating this issue is related to the diversity of language and the fact that CLIL has become prolific phenomenon in recent years, especially in pedagogical communication. The paper responds to different claims of the proponents of CLIL emphasizing its numerous benefits. Apart from that, the following paper provides a critical empirical examination of the positive CLIL outcomes in order to identify better its strengths in EFL. Due to distance, a sample of five Spanish teachers and five Slovak teachers at the primary level has been chosen randomly to respond to the online interview elaborating the use of CLIL in the classroom. In order to gain the results of the qualitative nature, the online interview included open-ended questions. Benefits of CLIL could be reflected in the enhanced motivation inside and outside the classroom, the need of students and teachers for critical thinking, requirement for a better concentration and in many other areas. The article presents current findings and brings the possibilities for implementing CLIL into more classrooms and enhancing pedagogical communication in foreign language classrooms.
\end{abstract}

Keywords: benefits, CLIL, language, motivation, student, teacher

\section{Introduction}

In recent years both, the area of foreign language teaching and the area of teaching in general have reflected that CLIL (Content and Language Integrated Learning) and its use in the classrooms might have a significant impact on the communication in the classroom. In spite of the fact that the approaches of this kind could carry with them various well-known limitations, use of CLIL could bring numerous benefits for teachers and students at the same time. By use of CLIL not only linguistic competence could be enhanced but also learners might be exposed to wider cultural context. This paper aims to contribute to this growing area of research by exploring the use of CLIL in the primary level classrooms in Spain and in Slovakia. In particular, the article is focused on the positive CLIL outcomes in order to identify better its strengths in EFL. 
Pavelová, 2020. Comparison of Content and Language Integrated Learning in the Primary Level in Spain and Slovakia

The main reason why Spain and Slovakia have been selected for this research is that the official language of both countries is different from English, whereas English is taught as a foreign language in both countries. This presupposes the ideal conditions for implementing CLIL into teaching and it is supported by the words of Cimermanová (2017, p. 1), who suggests that "its name directly indicates the aim of the methodology, namely to teach subjects as science, geography, arts through a foreign language." In other words, if science, arts, geography or any other subject is taught in English or any other foreign language, the language possibilities, teaching and learning possibilities might be expanded for teacher educators and students.

The other reason for comparison of CLIL approach in Spain and Slovakia is to look for similarities and differences in teaching in these two European countries. This paper seeks to address the following question: To what extent are Slovak and Spanish teachers familiar with the application of CLIL approach in the primary level? For this research, especially due to distance, a sample of five Spanish teachers and five Slovak teachers at primary level have been chosen randomly to respond to the online interview elaborating the use of CLIL in the classroom. In order to gain the results of the qualitative nature, the online interview included open-ended questions.

\section{Theoretical backdrop and Content and Language Integrated Learning in general}

While a variety of definitions of the term CLIL have been suggested, this paper will use the definition suggested by Straková \& Sepešiová (2015) according to whom CLIL is based on the common-sense belief that better learning takes place when learners are stimulated by the subject matter, hopefully out of interest but sometimes of necessity.

As McDougald (2018) notices, CLIL, if properly understood and used, should present ideal ways of focusing on language as a tool to access and share content knowledge. To be more explicit, in such ways, students are not merely exposed to the vehicular language, they also have opportunities to think in in the second language and produce meaningful content in the second language, supporting more rapid and practical acquisition of their second language skills in general. "CLIL represents the best framework for providing young learners the effective acquisition of some topics from the curriculum” (Bentley, 2010, p. 6).

CLIL applied in storytelling, for instance, could be one of the examples how to expose students to a variety of situations when students need to think in foreign language but is also provides students with the possibility to express themselves. On the top of that, storytelling and stories are a fundamental part of any literature and culture. With regards to CLIL and young learners, Bežilová (2019, p. 57) 
illustrates this point clearly, "literature allows children not only to understand but also to appreciate cultures different from their own."

With regards to foreign language teaching and learning, and on reviewing the last two decades from the initial inception of CLIL programmes in formal education at Primary and later Secondary levels, we are witnessing how the dualfocused approach of Content and Language Integrated Learning (CLIL) has been heralded as the lynchpin for change and success in language learning (Doiz, Lasagabaster, \& Sierra, 2014; Pérez Cañado, 2014). To be more specific, Lasagabaster (2011) notes that the dual role of language and content implies that proficiency is to be developed in both the non-language subject and the language in which it is taught, even though to achieve a strict balance of language and content is quite a challenging task. Therefore, it is necessary to highlight a phenomenon also known as a lack of cohesion around CLIL pedagogies (Coyle, 2008; Cenoz, Genesee, \& Gorter, 2014; Mehisto, 2008; Pérez-Vidal \& Juan-Garau, 2010). This has thrown up many questions in need of further investigation of CLIL (Pérez Cañado, 2018). Highlighting the particular areas of the research, Wolff (2005) considers the following CLIL investigations, which should be articulated: the effects of CLIL on the foreign language, the first language, subject content competence, and motivational aspects.

A considerable amount of literature has been published on particular aspects and effects of CLIL. A number of studies have found that, for instance with oral production and oral and written comprehension, experimental and control groups performed equally well on these aspects of second language learning. In particular, Admiraal, Westhoff, \& de Bot (2006), in Northern Europe, Serra (2007) conducted a longitudinal study in Switzerland, with Primary Education students. A similar focus on oral production has been put through Ruiz de Zarobe's (2008) longitudinal study with Basque CLIL and non-CLIL groups in the third and fourth year of Compulsory Secondary Education and in the second year of post-compulsory education. Speech production was assessed in terms of pronunciation, vocabulary, grammar, fluency, and content, with statistically significant differences being detected in favour of the CLIL groups (CLIL and CLIL with extra English literature classes). Most importantly, all three studies increased exposure and the CLIL program was found to positively impact oral competence skills.

Research such as the one carried out by Rallo Fabra \& Jacob (2015) who also worked with Secondary Education level in a Spanish bilingual community (in this case, the Balearic Islands), however, brought different results. In this study, the focus was put mainly on fluency and pronunciation within oral production, but the results were not as positive as with the study conducted by Ruiz de Zarobe (2008). The single most striking observation to emerge from the comparison of the studies was articulated by Pérez Cañado (2018, p. 54), “Over 
Pavelová, 2020. Comparison of Content and Language Integrated Learning in the Primary Level in Spain and Slovakia

the course of two years, no statistically significant differences emerged between the CLIL and non-CLIL branches on either fluency or pronunciation, casting doubt upon what can be considered sufficient time for CLIL to have an impact." This quotation, however, needs to be interpreted with caution. Bearing in mind that interpretation of these results refers to one study, it cannot be considered as a general statement with regards to implementation of CLIL.

\section{Content and Language Integrated Learning in Slovakia and in Spain}

One of the Slovak scholars who devoted a significant amount of time to CLIL research, S. Pokrivčáková, (2015) summarizes the current situation in applying CLIL at Slovak schools. The author emphasizes the difference between integrating CLIL in bilingual and mainstream schools. Unfortunately, there is no official statistical data indicating exact numbers of primary and secondary schools applying CLIL. However, based on the number of school projects and published works it can be concluded that the number of primary schools applying CLIL is much higher than the number of CLIL secondary schools Pokrivčáková (2015).

As for Slovakia, teachers who apply CLIL in their classes are typically nonnative teachers. According to Pokrivčáková (2015, p. 17), “most Slovak schools which apply CLIL integrate teaching in Slovak as a mother language and English as a foreign language.” The second most frequent foreign language that would be used within CLIL in Slovakia is German and just a few schools apply CLIL in Spanish and French or alternatively Russian and Italian, as these languages are considered as the second foreign languages (Pokrivčáková, 2015).

Trníková (2015, p. 49) identifies the goal of the CLIL methodology in primary school, which is to prepare learners for purposeful and intensive learning of foreign language in high school. Successful CLIL at primary level should fulfil the following principles:

- $\quad$ put the emphasis on communication,

- the basis for teaching process using CLIL is active listening,

- $\quad$ stimulate fluency of communication more than accuracy of language, accuracy is important only with pronunciation,

- teacher supports the creativity of learners by using open-ended or divergent assignments,

- teaching process is focusing on various learning styles of learners, teacher often switch various activities,

- $\quad$ special attention is focused on physical movement - motoric activity (e.g. TPR),

- $\quad$ teaching process is connected with the real world. 
Pokrivčáková (2015) illustrates the following classification of the CLIL research in Slovakia:

- learner-oriented CLIL research,

- teacher-oriented CLIL research,

- language-based CLIL research.

Turning now to the situation of CLIL in Spain, Coyle (2010), for instance, highlighted the richness of Spanish cultural diversity, which has led to a wide variety of CLIL policies and practices. Moreover, this provided numerous examples of CLIL in different stages of development that are applicable to contexts within and beyond Spain. As more authors agree CLIL methodology is currently experiencing a rapid development in Spanish educational settings, Therefore, it is becoming a popular term in the teaching practice over the last years (Huguet, Lasagabaster, \& Vila, 2008; Muñoz \& Navés, 2007).

Similarly, as in Slovakia, Spanish primary teachers applying CLIL in teaching are generally non-native language specialists. The only exception is the programme, which is collaboratively run with the British Council with a significant number of native English-speaking teachers (Muñoz \& Navés, 2007). Another similarity between CLIL in Slovakia and CLIL in Spain is that "the target language of CLIL is English, which is the first foreign language in most schools and for most students. French, which used to be the first foreign language, is also present but to a lesser extent” (Muñoz \& Navés, 2007, p.164). The evidence presented in this section suggests that there are similarities between CLIL in Spain and in Slovakia. However, the aim of the article is not to provide a detailed description of similarities or differences, rather to present a brief outline of applying CLIL in the primary level in both countries.

\section{Research materials and methods}

The paper uses qualitative analysis in order to gain insights into teachers' perception of CLIL, particularly, to get information about CLIL application in the primary level. A sample of the primary school teachers from both countries was selected randomly. On purpose, the sample did not consist only of the teachers from the Primary Schools where CLIL is applied in teaching regularly or for a longer period of time. As for Spain, the sample of the respondents consisted of the teachers from Logroño, Madrid, Santander \& Zaragoza. In Slovakia, the sample also included primary school teachers from the different parts of the country. In order to get reliability and validity of the research and, most importantly, to get data of the qualitative nature, the online interview with openended questions was used. The aim of the online interview was to get an insight into the reasons and possibilities of applying or not applying CLIL in the classes 
Pavelová, 2020. Comparison of Content and Language Integrated Learning in the Primary Level in Spain and Slovakia

of the selected teachers. The online interview consisted of the following questions:

1. What is CLIL?

2. What are the benefits of having a CLIL classroom?

3. What do you understand under the 'four C's of CLIL'?

4. What are the essential features of a CLIL curriculum?

5. How do you know if you are already a CLIL teacher?

6. What is the role of the instructor in a CLIL classroom?

7. What are the key elements of a CLIL lesson plan?

8. How popular is CLIL approach in your country? $(0-100 \%)$

9. Which subjects do you teach through CLIL?

10. What is the feedback of your students on the use of CLIL?

The data had been collected in December 2019 and early January 2020 and accordingly analysed. The questions were divided into two parts. The first part covers the questions 1-8 and provides general information about CLIL, its application in the classroom and similarities or differences that might occur within this approach in both countries. The aim of this part of the online interview was to get an insight into the respondents' understanding of CLIL. Additionally, the questions were designed in a way that the respondents could have provided the answers based on their own experience. The second part of the questions, 9-10, is more personal, as each CLIL teacher might apply CLIL in different subjects and feedback from the students could also differ a lot.

\section{Data analysis and discussion of the results}

This part of the article discusses the interpretation of the results which emerged from the gathered data. Therefore, these results need to be interpreted with caution. The article does not comment on every single answer of each of the respondents, as many answers were similar. However, data analysis highlights the most significant parts of the online interview.

It would remiss not to elaborate the question, which relates to the benefits of CLIL. As the questions were open-ended, the aim of the questions was to get a proper insight, own ideas of the teachers and not definitions. One of the Spanish teachers brought an interesting point, "Thanks to CLIL, my students started talking aloud in the classroom. I have been trying to use this method for about three years now and I have been given the same groups of students within these three years. Not only they are more fluent and accurate, but I have observed how their personalities changed and they feel free to talk about any issue in English, as it is their second language." Another Spanish teacher added that "It is really surprising to watch students if they are given a task when they need to argue. I consider the major benefit of CLIL that students use all sorts of vocabulary. It is 
not geography only, for example. I appreciate that they try to think in the second language." On the contrary, speaking of benefits of CLIL, one of the Slovak teachers noted, "I wish I had known more about CLIL and more of my colleagues would be open to try it. We don't use it in our school." Speaking of benefits of CLIL, majority of the teachers found its numerous benefits, mainly in creative ways of improvement of the second language. However, they expressed a need to talk about CLIL often and to learn more about CLIL. There have been provided a number of other similar examples and statements from Slovak as well as Spanish teachers struggling with similar issues and challenges.

Another point worth to mention was the question which dealt with the role of the instructor in the classroom. One of the teachers provided the following illustration of her role, "CLIL made me think that my role as a role of instructor is highly important. Once I set clear instructions for my students, things work well for us. Sometimes I feel like I need to be an interpreter, some parts I mean, but it always reminds me that a teacher might take a few different roles within one lesson." However, in response to this question, one of the Spanish teachers indicated that CLIL should be learner-centred method and therefore teacher should act as facilitator.

Regarding the question of CLIL lesson planning, almost all teachers (those who apply CLIL in teaching as well as those who are not familiar with CLIL) noted that the major feature of CLIL lesson plan should be novelty of the tasks and engaging tasks. At the same time, all Slovak teachers expressed uncertainty related to CLIL lesson planning. Apart from that, three Spanish teachers considered authenticity of the tasks as the most important element of CLIL lesson planning.

When the participants were asked how popular CLIL teaching is in their country, four out of five Spanish teachers mentioned that CLIL is highly popular. As for Slovak teachers, three of them commented that according to them, CLIL is very popular because they attended CLIL seminars in Slovakia and abroad.

For the question related to subjects taught through CLIL, the answers included mainly geography, history, music and arts.

In response to the question "What is the feedback of your students on the use of CLIL?”, a range of responses was elicited. Obviously, feedback of the students who know CLIL, was very positive. On the other hand, two teachers from both countries emphasized that their beginnings of CLIL application into teaching were difficult and students were reluctant to get used to it.

To sum it up, the sample of the teachers from both countries indicated that even though CLIL is undoubtedly useful and beneficial in teaching, it requires a great amount of time to be confident in CLIL teaching. Almost two-thirds of the participants said that there should be more cooperation among language teachers 
Pavelová, 2020. Comparison of Content and Language Integrated Learning in the Primary Level in Spain and Slovakia

and subject teachers, since this might create suitable conditions for the application of CLIL approach.

\section{Conclusion}

The aim of the presented article was to introduce the current views on the use of CLIL in the primary level in Spain and in Slovakia. A sample of primary school teachers from both countries had been given a chance to comment objectively on CLIL approach, whether they apply CLIL in teaching and to provide the reasons for using or not using CLIL approach in teaching. The article aimed to compare and elaborate sufficient (or insufficient) readiness of the selected teachers and primary schools for CLIL in linking theory with practice based on the online interview.

The present results are significant in at least two major respects. The teachers responding to the online interview realize how useful CLIL is not only for their current teaching, their students but also for their future. As Oxbrow highlights the importance of CLIL, "it is arguably the most innovative didactic reform of the last couple of decades in response to the emergent twenty-first century need for multilingual citizens who need to be competent in more than one language" (Oxbrow, 2018, pp. 137-138). This finding has important implications for creating more opportunities, workshops, seminars aimed at CLIL for both teachers and students. The more confident teachers are and the more they believe in their ability to apply CLIL at the lesson, the easier it could be for them to perform at any lesson, bearing in mind that CLIL brings a full variety of benefits for their students too.

The results of the online interview offer an answer to the question: To what extent are Slovak and Spanish teachers familiar with the application of CLIL approach in the primary level? Even though CLIL approach has been applied in teaching for a number of years, the teachers from both countries would prefer if this topic was researched more. In addition, the article offers some important insights into CLIL teaching in primary schools in both countries and provides readers with the ideas that could be possibly implemented in teaching, so that the educational process could be improved. The reader should bear in mind that the results gained from the online interview should not be interpreted in general, as the sample was small and random. Another limitation of the study is the fact that not all the teachers responding to the online questionnaire apply CLIL in teaching. A full discussion of CLIL approach, its comparison in the primary level in Spain and in Slovakia lies beyond the scope of this paper. 
SOCIETY. INTEGRATION. EDUCATION

Proceedings of the International Scientific Conference. Volume III, May $22^{\text {th }}-23^{\text {th }}$, 2020. 437-446

\section{Acknowledgements}

This study derived from a governmentally-funded research project financed by the Slovak Ministry of Education, Science, Research and Sport (research grant number KEGA project No. 032PU-4/2019, project: Vytvorenie učebných materiálov pre učitel'ov základných škôl pre integrovanie jazykového a obsahového vyučovania).

\section{References}

Admiraal, W., Westhoff, G., \& de Bot, K. (2006). Evaluation of bilingual secondary education in The Netherlands: Students' language proficiency. English Educational Research and Evaluation, 12(1), 75-93.

Bentley, K. (2010). The TKT course: CLIL module. Cambridge: Cambridge University Press.

Bežilová, V. (2019). The Effect of Storytelling on Longer Vocabulary Retention. Contemporary research in education and English language teaching, 1(1), 57-62.

Bruton, A. (2011b). Is CLIL so beneficial, or just selective? Re-evaluating some of the research. System, 39(4), 523-532.

Cenoz, J., Genesee, F., \& Gorter, D. (2014). Critical analysis of CLIL: Taking stock and looking forward. Applied Linguistics, 35(3), 243-262.

Cimermanová, I. (2017). CLIL - a Dialogue between the Language and Subject Teachers. Scientia et eruditio [elektronický zdroj], 1(1), 1-14. DOI: https://doi.org/10.31262/ 2585--8556/2017/1/1/1--14

Coyle, D. (2008). CLIL - A pedagogical approach from the European perspective. In Van Dusen-Scholl \& N.H. Hornberger (Eds.), Encyclopedia of Language and Education (pp. 97-111). New York: Springer.

Coyle, D, Hood, P., \& Marsh, D. (2010). CLIL. Content and language integrated learning. Cambridge: CUP.

Coyle, D. (2013). Listening to learners: an investigation into 'successful learning' across CLIL contexts. International Journal of Bilingual Education and Bilingualism, 16(3), 244-266.

Doiz, A., Lasagabaster, D., \& Sierra, J.M. (2014). CLIL and motivation: the effect of individual and contextual variables. The Language Learning Journal, 42(2), 209-224.

Fernández, D.M., Ortega-Martín, J.L., \& Hughes, S.P. (2019). CLIL and Language Education in Spain. In Tsuchiya, K. \& Peréz-Murillo, M. D. (Eds.), Content and Language Integrated Learning in Spanish And Japanese Contexts (pp. 11-36). Springer.

Huguet, A., Lasagabaster, D., \& Vila, I. (2008). Bilingual education in Spain: Present realities and future challenges. In J. Cummins \& N.H. Hornberger (Eds.), Encyclopedia of language and education (pp. 25-235). New York: Springer Science. http://dx.doi.org/10.1007/978-0-387-30424-3_127

Lasagabaster, D., \& Ruiz de Zarobe, Y. (2010). Ways forward in CLIL: Provision issues and future planning. In D. Lasagabaster \& Y. Ruiz de Zarobe (Eds.), CLIL in Spain: Implementation, results and teacher training (pp. 278-295). Newcastle upon Tyne: Cambridge Scholars Publishing.

Lasagabaster, D. (2011). English achievement and student motivation in CLIL and EFL settings. Innovation in Language Learning and Teaching 5(1), 3-18. 
Pavelová, 2020. Comparison of Content and Language Integrated Learning in the Primary Level in Spain and Slovakia

McDougald, J.S. (2018). CLIL across the Curriculum: Benefits that go beyond the classroom. LACIL 11(1), 9-18.

Mehisto, P. (2008). CLIL counterweights: Recognising and decreasing disjuncture in CLIL. International CLIL Research Journal 1(1), 93-119.

Muñoz, C., \& Navés, T. (2007). CLIL in Spain. In D. Marsh \& D. Wolff (Eds.) Windows on CLIL. Content and Language Integrated Learning in the European Spotlight (pp. 160-165). The Netherlands: European Centre for Modern Languages.

Oxbrow, G.L. (2018). Students' Perspectives on CLIL Program: A Quantitative Analysis. Porta Linguarum, 29, 137-158.

Pérez Cañado, M.L. (2014). Teacher training needs for bilingual education: In-service teacher perceptions. International Journal of Bilingual Education and Bilingualism, 19(3), 266-295.

Pérez Cañado, M.L. (2018). CLIL and Educational Level: A Longitudinal Study on the Impact of CLIL Outcomes. Porta Linguarum, 1, 51-70.

Pérez-Vidal, C., \& Juan-Garau, M. (2010). To CLIL or not to CLIL: From bilingualism to multilingualism in Catalan/Spanish communities. In D. Lasagabaster \& Y. Ruiz de Zarobe (Eds.), CLIL in Spain: Implementation, Results and Teacher Training (pp. 115-138). Newcastle-Upon-Tyne: Cambridge Scholars Publishing.

Pokrivčáková, S. (2015). CLIL in Slovakia: projects, research, and teacher training. In Pokrivčáková, S. et al. (Eds.), CLIL in Foreign Language Education: e-textbook for foreign language teachers (pp. 17-29). Nitra: Constantine the Philosopher University.

Rallo Fabra, L., \& Jacob, K. (2015). Does CLIL Enhance Oral Skills? Fluency and Pronunciation Errors by Spanish-Catalan Learners of English. In M. Juan-Garau \& J. Salazar-Noguera (Eds.), Content-based Language Learning in Multilingual Educational Environments, Educational Linguistics 23 (pp. 163-178). Springer Cham Heidelberg New York Dordrecht London.

Ruiz de Zarobe, Y. (2008). CLIL and Foreign Language Learning: A Longitudinal Study in the Basque Country. International CLIL Research Journal, 1(1), 60-73.

Serra, C. (2007). Assessing CLIL at Primary School: A Longitudinal Study. International Journal of Bilingual Education and Bilingualism, 10(5), 82-602.

Straková, Z., \& Sepešiová, M. (2015). CLIL in Reading Programmes. In Hanesová, D. (Ed.), Learning together to be a better CLIL teacher (pp. 99-107). Banská Bystrica: UMB.

Trníková, J. (2015). Primary CLIL. In Pokrivčáková, S. et al. (Ed.), CLIL in Foreign Language Education: e-textbook for foreign language teachers (pp. 45-59). Nitra: Constantine the Philosopher University. 